\title{
Effects of climate-induced changes in isoprene emissions after the eruption of Mount Pinatubo
}

\author{
P. J. Telford ${ }^{1}$, J. Lathière ${ }^{2,3,4}$, N. L. Abraham ${ }^{1}$, A. T. Archibald ${ }^{1}$, P. Braesicke ${ }^{1}$, C. E. Johnson ${ }^{5}$, O. Morgenstern ${ }^{1, *}$, \\ F. M. O'Connor ${ }^{5}$, R. C. Pike ${ }^{1}$, O. Wild ${ }^{3}$, P. J. Young ${ }^{1, * *}$, D. J. Beerling ${ }^{2}$, C. N. Hewitt ${ }^{3}$, and J. Pyle ${ }^{1}$ \\ ${ }^{1}$ Centre for Atmospheric Science, Department of Chemistry, University of Cambridge, Cambridge CB2 1EW, UK \\ ${ }^{2}$ Department of Plant and Animal Sciences, University of Sheffield, Sheffield, UK \\ ${ }^{3}$ Lancaster Environment Centre, Lancaster University, Lancaster LA1 4YQ, UK \\ ${ }^{4}$ now at Laboratoire des Sciences du Climat et de l'Environment, Gif sur Yvette, France \\ ${ }^{5}$ Met Office Hadley Centre, Exeter, UK \\ *now at: National Institute of Water and Atmospheric Research, Lauder, New Zealand \\ ** now at: NOAA Earth System Research Laboratory, Boulder, Colorado 80305, USA
}

Received: 13 February 2010 - Published in Atmos. Chem. Phys. Discuss.: 11 March 2010

Revised: 11 June 2010 - Accepted: 11 July 2010 - Published: 3 August 2010

\begin{abstract}
In the 1990s the rates of increase of greenhouse gas concentrations, most notably of methane, were observed to change, for reasons that have yet to be fully determined. This period included the eruption of Mt. Pinatubo and an El Niño warm event, both of which affect biogeochemical processes, by changes in temperature, precipitation and radiation. We examine the impact of these changes in climate on global isoprene emissions and the effect these climate dependent emissions have on the hydroxy radical, $\mathrm{OH}$, the dominant sink for methane. We model a reduction of isoprene emissions in the early 1990s, with a maximum decrease of $40 \mathrm{Tg}(\mathrm{C}) / \mathrm{yr}$ in late 1992 and early 1993, a change of $9 \%$. This reduction is caused by the cooler, drier conditions following the eruption of Mt. Pinatubo. Isoprene emissions are reduced both directly, by changes in temperature and a soil moisture dependent suppression factor, and indirectly, through reductions in the total biomass. The reduction in isoprene emissions causes increases of tropospheric $\mathrm{OH}$ which lead to an increased sink for methane of up to 5 $\operatorname{Tg}\left(\mathrm{CH}_{4}\right)$ /year, comparable to estimated source changes over the time period studied. There remain many uncertainties in the emission and oxidation of isoprene which may affect the exact size of this effect, but its magnitude is large enough that it should remain important.
\end{abstract}

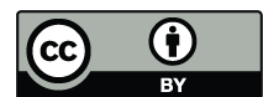

Correspondence to: P. Telford (paul.telford@atm.ch.cam.ac.uk)

\section{Introduction}

In the early 1990s the rate of increase in the concentrations of several greenhouse gases, including methane and carbon dioxide, dropped significantly (Dlugokencky et al., 2003; Denman et al., 2007). These changes occurred close to the eruption of Mt. Pinatubo (June 1991) and a strong warm phase of the El Niño Southern Oscillation (ENSO) (19921993). The causes of these changes have yet to be fully ascertained, with changes of radiation, temperature, and precipitation being proposed (Bekki et al., 1994; Warwick et al., 2002; Johnson et al., 2002; Gedney et al., 2004).

The changes were most dramatic in methane, for which changes in both sources and sinks have been proposed. Wang et al. (2004) and Bousquet et al. (2006) attributed most of the decrease to a reduction of anthropogenic emissions following the break up of the USSR. However, as they noted, there are other causes of variability, including changing emissions from wetlands (Gedney et al., 2004), changes in meteorology (Warwick et al., 2002) and changes in the concentration of $\mathrm{OH}$, the dominant sink of methane. Although there is no evidence for large changes in $\mathrm{OH}$ (Krol and Lelieveld, 2003; Bousquet et al., 2005) over this time its short lifetime make determinations of trends difficult, even when observations are augmented by modelling studies. There have been several modelling studies of the 1990s that considered possible changes in $\mathrm{OH}$ caused by changes in emissions of $\mathrm{NO}_{\mathrm{x}}$ and CO (Dalsøren and Isaksen, 2006), humidity (Johnson et al., 2002) and UV radiation, which affects photolysis in the troposphere (Bekki et al., 1994). A further factor could

Published by Copernicus Publications on behalf of the European Geosciences Union. 
have been changes in emissions of biogenic volatile organic compounds, of which isoprene is probably the most important (Guenther et al., 2006), and their subsequent impact on tropospheric oxidising capacity. Here we investigate the contribution to methane variability of changes in $\mathrm{OH}$ caused by climate-induced variations in biogenic emissions of isoprene.

Isoprene is a reactive organic compound emitted in large amounts by many plant species around the globe, mainly in tropical forests. Recent estimates of emissions are around $500 \mathrm{Tg}(\mathrm{C})$ per year (Guenther et al., 2006), an amount comparable to the total emission of methane (Lelieveld et al., 1998). Once emitted isoprene reacts rapidly with $\mathrm{OH}$ and ozone directly affecting the oxidising capacity of the atmosphere. The amount of isoprene emitted is sensitive to changes in temperature, humidity, insolation and precipitation; see for example Sharkey et al. (2007).

The eruption of Mt. Pinatubo and a strong positive phase of the ENSO changed these factors, which would have affected isoprene emissions. Mount Pinatubo erupted in June 1991, injecting sulfate aerosol into the stratosphere reducing the radiation reaching the surface and producing global cooling in the troposphere (McCormick et al., 1995). The sulfate aerosol also depleted stratospheric ozone increasing the amount of UV radiation reaching the troposphere (Bekki et al., 1994). In addition, there was a pronounced El Niño event in 1992 and 1993 (Wolter and Timlin, 1993). This changed temperature and precipitation patterns, especially in the tropics.

We use climate-dependent isoprene emissions in an integration with the UKCA chemistry-climate model (O'Connor et al., 2009) from 1990 to 1995 which we constrain to meteorological analyses to obtain the observed climatic changes. We then compare this with a run where isoprene emissions are kept at levels modelled before the eruption to assess the effect of the climate dependent emissions. In addition, to assess the impact of meteorology, we compare the Base run to one where the meteorology is nudged to 1990 .

Our model is not a fully coupled Earth system model. Nevertheless we believe that it allows an important preliminary investigation of potentially significant coupling processes in the Earth system. Some processes are ignored, such as changes in methane emissions, but this simplified modelling framework allows the effect of other processes, like climate related biogenic emissions, to be considered. We believe that this is an important step in developing process understanding and towards developing more sophisticated models.

\section{Model description}

We use a nudged version (Telford et al., 2008) of the UKCA model (Morgenstern et al., 2009; O'Connor et al., 2009). It is based upon an atmosphere only version of the Met Office's Unified Model (UM), with the following configuration:
- a horizontal resolution of $3.75^{\circ} \times 2.5^{\circ}$ in longitude and latitude.

- 60 hybrid height levels in the vertical, from the surface up to a height of $84 \mathrm{~km}$.

- a dynamical time-step of $30 \mathrm{~min}$.

A time series of sea surface temperatures and sea ice coverage are prescribed from the HadISST dataset (Rayner et al., 2003). The technique of nudging is used to reproduce the atmospheric conditions over the period studied. This constrains the model horizontal winds and temperatures to ERA40 re-analysis data (Uppala et al., 2005). The nudging is applied from 3 to $45 \mathrm{~km}$ with a relaxation time scale of $6 \mathrm{hrs}$ (Telford et al., 2008).

We use the tropospheric version of the UKCA chemistry model (O'Connor et al., 2010), with a chemistry scheme based on that used in Law et al. (1998) and Young et al. (2009). The scheme, as described by Pike et al. (2009), is medium sized and simulates the $\mathrm{O}_{\mathrm{x}}, \mathrm{HO}_{\mathrm{x}}$ and $\mathrm{NO}_{\mathrm{x}}$ chemical cycles and the oxidation of $\mathrm{CO}$, ethane, propane, and isoprene. The Mainz isoprene mechanism (MIM) (Pöschl et al., 2000) is used to parameterise isoprene oxidation. The model has 132 chemical reactions and 60 chemical tracers. To provide a realistic upper boundary condition for the tracers concentrations of ozone and $\mathrm{NO}_{\mathrm{y}}$ are overwritten above $30 \mathrm{hPa}$ from zonal mean values from the Cambridge 2D model (Law and Pyle, 1993a,b). We overwrite methane to be $1.76 \mathrm{ppmv}$ throughout the atmosphere, to reduce the time required to equilibrate the model.

Photolysis rates are calculated using the off-line scheme of Law et al. (1998) ${ }^{1}$. Dry deposition is parameterised based on the scheme of Giannakopoulos et al. (1999). Wet deposition is described as a first order loss process from the rainfall rates generated by the model (Giannakopoulos et al., 1999). Eight chemical species are emitted in the model in the manner of Zeng and Pyle (2003). The species emitted are NO, $\mathrm{CO}, \mathrm{HCHO}$, ethane, propane, acetaldehyde, acetone, and isoprene. Climatological industrial and biomass burning emissions are taken from Stevenson et al. (2006) with the addition of aircraft emissions (Eyers et al., 2004), $5 \mathrm{Tg}$ of nitrogen per year from lightning (Price and Rind, 1994) and $30 \mathrm{Tg}$ carbon per year from biogenic acetone emissions.

The isoprene emissions are determined separately using a two stage process. First the SDGVM, a dynamic vegetation model (Beerling et al., 1997; Beerling and Woodward, 2001), is used to create time varying global maps of vegetation types using monthly mean meteorological output (surface temperature, sw radiation flux, humidity and precipitation) from a nudged UKCA integration of this period (Telford

\footnotetext{
${ }^{1}$ The effect of changes in UV penetration due to the eruption are not included in the photolysis rate calculation in this study. But they do influence the photosynthetically active radiation in the emissions calculation.
} 


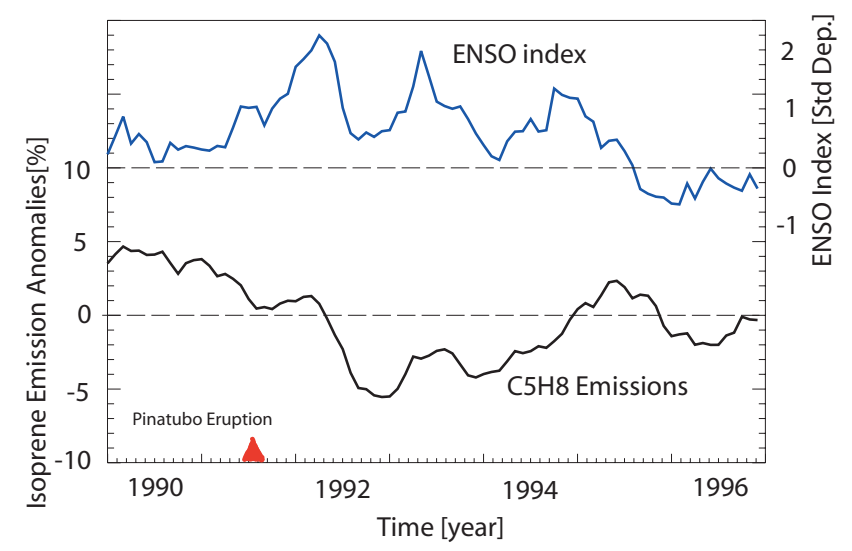

Fig. 1. Anomalies in global isoprene emissions (black line). A six month running mean is applied to show the long term trends. The ENSO index of Wolter and Timlin (1993) is included for reference (blue line). The reduction in emissions after the eruption of $\mathrm{Mt}$ Pinatubo (marked by a red triangle) is clear.

et al., 2009). We use UKCA output for consistency of climate between the emissions model and the chemistry model. This output includes the changes to climate, including temperature and precipitation, and changes to SW flux from changes in aerosol, ozone and clouds. The vegetation model provides information on the fraction of each grid-point occupied by each vegetation type, and represents the amount of biomass for each vegetation type through a "leaf area index". A biogenic emissions model (Lathière et al., 2010), following the empirical parameterisation of the MEGAN model (Guenther et al., 2006), then combines these maps with the meteorological output to produce isoprene emissions.

The emissions are calculated at standard conditions and then multiplied by the product of three non dimensional activity factors to account for deviations from this standard. These factors are the canopy environment emission activity factor, the leaf age emission activity factor and the soil moisture activity factor. The canopy emission activity factor parameterises variation due to leaf area, light and temperature within the canopy. The leaf age emission activity factor makes adjustments to account for the effects of leaf age. The soil moisture activity factor accounts for direct changes caused by soil moisture. A detailed description of the parameterisations can be found in Guenther et al. (2006) and Lathière et al. (2010).

\section{Changes in isoprene emissions}

First we analyse the changes in calculated isoprene emissions during the early 1990s. Figure 1 shows the anomalies in the global modelled isoprene emissions from 1990-1996, calculated with respect to the average annual cycle over the period. 6 month smoothing has been applied to highlight the interannual variation. The eruption of Mt. Pinatubo in July 1991 is

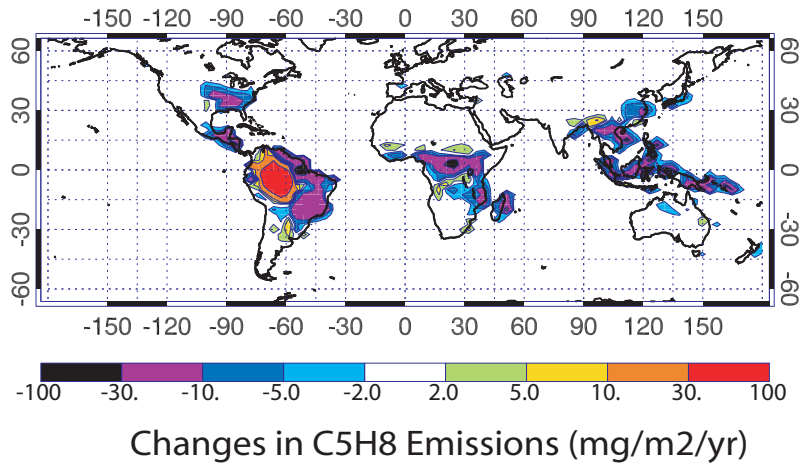

Fig. 2. Distribution of differences in annual mean isoprene emissions before and after the eruption of Mt. Pinatubo (1992-1990).

marked by a red triangle at the bottom of the plot. In addition we include the multi-variate ENSO index of Wolter and Timlin (1993). This combines sea level pressure, zonal and meridional winds, sea surface temperature, air surface temperature and total cloudiness to indicate the phase of ENSO. Positive deviations from zero indicate more El Niño like conditions, negative deviations more La Niña like conditions.

Lathière et al. (2006) and Müller et al. (2008) have already demonstrated that ENSO warm events are linked to increases in global isoprene emissions when using similar parameterisations to model emissions. Examining Fig. 1 there seems to be some link, with the lowest isoprene emissions being modelled at the time of lower values of the ENSO index. However even if we use the lag of 6 months as suggested by Müller et al. (2008) we do not produce a significant correlation over time between the two. Lathière et al. (2006) note that the relationship is weaker during the 1992 El Niño warm event, which they attribute to temperature increases over South America being smaller than normal. This cooling was caused by the eruption of Mt. Pinatubo (McCormick et al., 1995) and suggests that the eruption disrupted the normal link between ENSO and isoprene emissions. We next examine the spatial differences of the changes to see whether they provide more information, before exploring the individual drivers of the changes in emissions in Section 3.2 .

\subsection{Distribution of changes in isoprene emissions}

We concentrate on the distribution of changes in isoprene emissions in 1992. This is when we should expect high emissions from the El Niño event, but when instead we see the lowest values of emissions (see Fig. 1). Figure 2 shows the annually averaged difference in isoprene emissions between 1992 and 1990. We use 1990 as our control distribution, rather than a multi-year average, to ensure we have no contribution from the eruption. The isoprene emissions in 1992 are reduced in most of the isoprene emitting regions. The most striking exception is the western Amazon where we see large increases. 
As there are no large scale measurements of isoprene emission fluxes in the early 1990s we cannot validate these results directly, although the MEGAN parameterisation performs reasonably well when tested (Guenther et al., 2006). Barkley et al. (2008) infer isoprene emissions from South America from HCHO column measurements later in the decade, and see increases in emissions in 1997 in the western Amazon related to an ENSO warm phase. This suggests that our increases in the western Amazon seen in Fig. 2 could be realistic and can be attributed to the ENSO warm phase. Their measurements do not show an obvious decrease over eastern Brazil, though emissions are harder to determine here because of contamination from $\mathrm{HCHO}$ produced by biomass burning. It could also reflect that the changes in 1992 are different from those in the 1997 because of effects of the eruption, making full validation impossible.

\subsection{Drivers of isoprene emissions}

To investigate the causes of the changes in emissions we proceed to examine the drivers of the emissions and vegetation models. Figure 3 shows the annual mean changes between 1992 and 1990 in the drivers of isoprene emissions; precipitation, relative humidity, short-wave radiation and temperature. In addition we include changes in diagnostics from the vegetation and emissions model: leaf area index and soil moisture activity factor. The spatial distribution of the differences in these climate related variables gives evidence of the warm phase of the ENSO, with warmer drier conditions in the eastern Pacific, South America and southern Africa, resembling the changes noted by Qian et al. (2008).

The complex nature of the emissions algorithm makes establishing the exact causes of changes in emissions difficult. We take a simple approach and correlate the changes in driving factors and the emissions from which we find that the temperature was found to have the largest impact, with a spatial correlation in the tropics of 0.21 . The relationship is even stronger in North America with a spatial correlation coefficient of 0.69 . This suggests that the main cause of decreased isoprene emissions after the eruption of Mt. Pinatubo was the global cooling observed and that the increased emissions in the Amazon basin are related to local warming caused by the ENSO warm phase.

However the relationship is not quite that simple, with there being regions, such as north-eastern Brazil and southern Africa where there were increases in temperature but decreases in emissions. Indeed the region with the largest temperature increases is exactly the region with some of the largest decreases in emissions. This is consistent with the results of Sanderson et al. (2003) who note that, whilst in general isoprene emissions are correlated with temperature, there are regions where changes in vegetation are more important than temperature effects.

We use the leaf area index (LAI) from the SDGVM, shown in the bottom left of Fig. 3, to examine changes in vegetation.
The LAI is the leaf area per surface area in the model and as such represents modelled biomass. In north-eastern Brazil there are large decreases in LAI between 1990 and 1992, indicating decreases in biomass. This is consistent with the results of Tian et al. (1998), who simulate decreases in biomass in ENSO warm phases in this region. We simulate similar decreases of leaf area in parts of Africa, like Milton and Dean (2000) who see reductions of biomass in Africa at this time. These reductions in biomass are a result of reduced precipitation and also contribute to reductions in isoprene emissions. The changes in precipitation are caused by ENSO and the eruption of Pinatubo affecting the hydrological cycle. It is not possible to determine the relative importance of these two factors, though Trenberth and Dai (2007) observe that the eruption produces a global decrease in precipitation over land unlike El Niño events which merely tend to alter its distribution.

We have also examined the activity factors used in MEGAN and find that there are changes in the soil moisture activity factor, shown in the bottom right of Fig. 3. Decreases in the soil moisture activity factor augment the reduction in isoprene emissions through much of the tropics caused by decreases in biomass, most notably in the Amazon and southern and eastern Africa. However the effects of changes in soil moisture activity are smaller and more uncertain than the effects of biomass changes, with its parameterisation still not well constrained.

\subsection{Conclusions about isoprene emissions}

We see a reduction of $9 \%$ in isoprene emissions between 1990 and 1992. In 1992 these decreases are seen throughout the globe and are linked to cooler and drier conditions after the eruption of Mt. Pinatubo. These conditions reduce modelled emissions, directly through the MEGAN parameterisation and indirectly through reductions in biomass. The impact of the El Niño event can be seen in the western Amazon where warmer conditions produce increases in isoprene emissions. Globally the effects of the eruption dominate. We now proceed to investigate the effect of these emission changes on tropospheric chemistry.

\section{Impact of isoprene emissions of $\mathrm{OH}$ and methane}

Isoprene is the volatile organic compound with the highest emissions into the atmosphere (Guenther et al., 2006) and as such impacts strongly on the tropospheric $\mathrm{OH}$ concentration. We perform runs of the UKCA chemistry climate model to investigate the effect of changes in isoprene emissions during the early 1990s.

\subsection{Methodology}

We perform two model runs to isolate the impact of the changes in isoprene emissions. The first, which we denote 

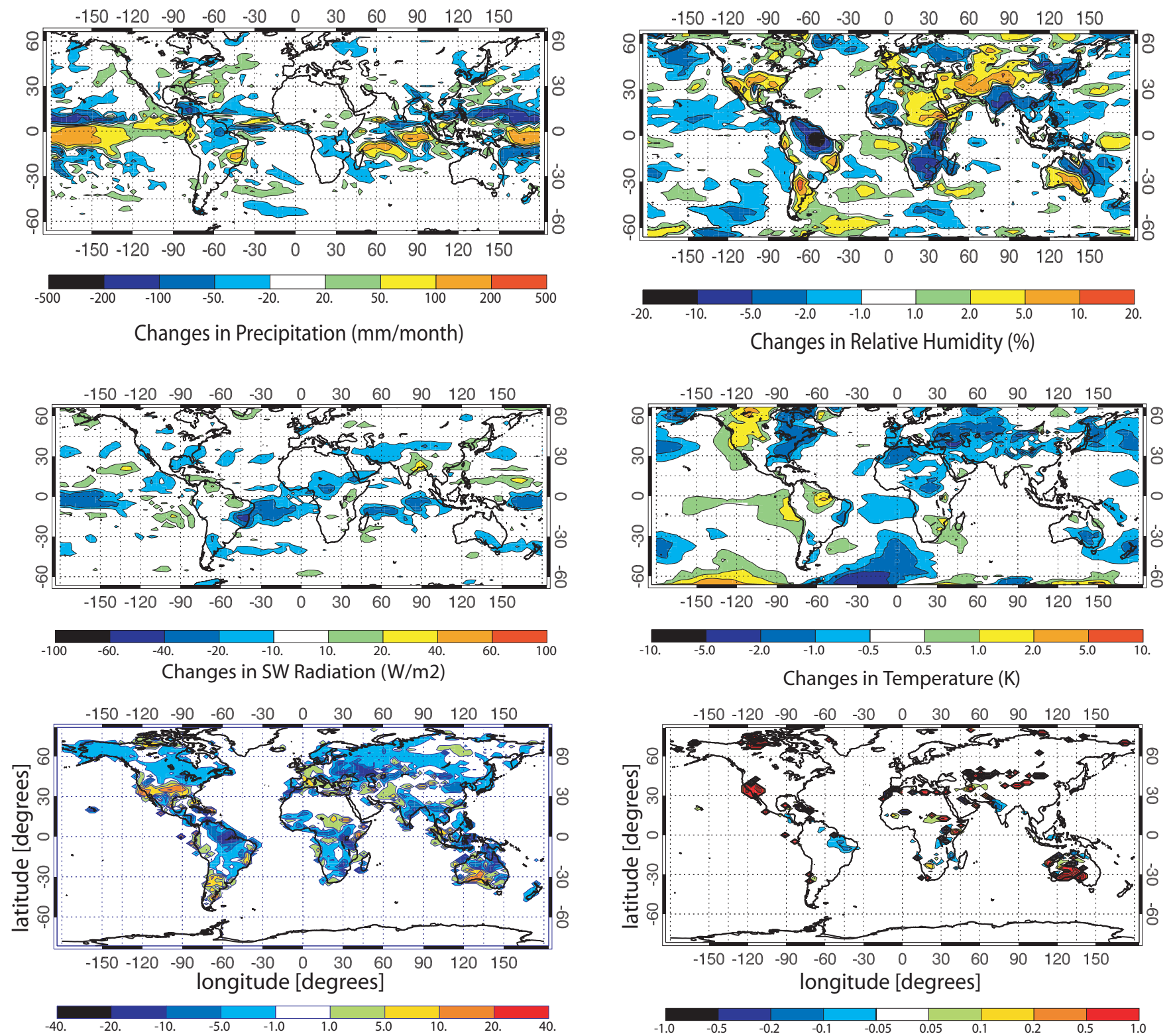

Changes in Leaf Area Index (m2/m2)

Changes in Soil Moisture Activation Factor

Fig. 3. Differences, between 1992 and 1990, of drivers of isoprene emissions and selected diagnostics from the isoprene emissions calculation.

the Base run, utilises all aspects of the model nudging to ERA-40 analyses and with time varying isoprene emissions. The second run, which we denote the Emfix run, is identical to the first with the exception that emissions are fixed to 1990 levels, which we use because it is free of the influence of the eruption. The effect of the inter-annually varying, climatedependent isoprene emissions is determined from the difference between the Base and Emfix runs.

In addition we include a third run, the Metfix run, identical to the Base run, including time varying emissions, ex- cept that the meteorology is always nudged to 1990 fields. The impacts of inter-annual variations in meteorology are determined from the difference between the Base run and this Metfix run.

The different model runs and emissions data sets are not intended to isolate the separate effects of the Pinatubo eruption and ENSO. Instead we can only look at the combined effect of all climate signals on isoprene emissions and meteorology. Whilst we can infer something about the relative importance of the eruption and ENSO by examining factors 


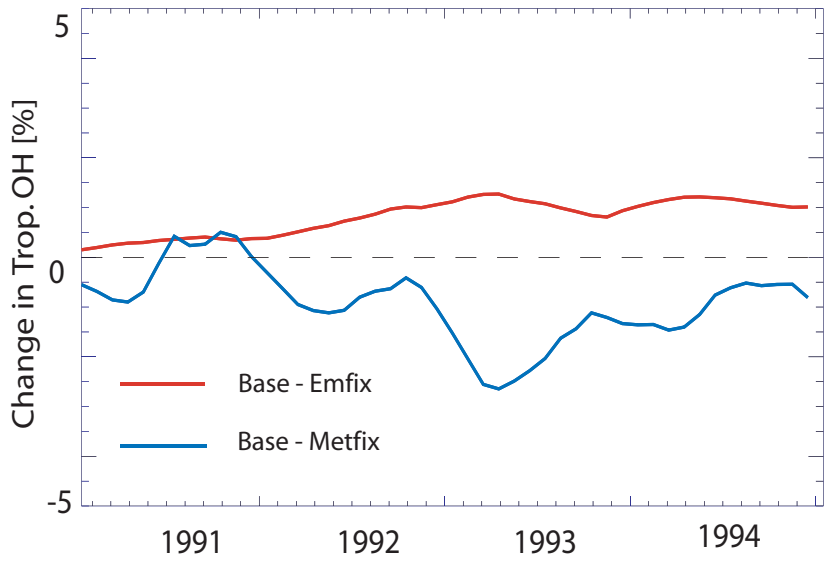

Fig. 4. Difference in tropospheric $\mathrm{OH}$ burden between Base and Emfix runs (red line) and Base and Metfix runs (blue line). A six month running mean is applied to show the long term trends.

such as the spatial distribution of the changes, the set up of the different runs does not allow us to discriminate between these factors.

\subsection{Global impact on oxidising capacity and methane}

Figure 4 shows the differences in tropospheric $\mathrm{OH}$ burdens between the Base and Emfix runs and the Base and Metfix runs. The difference between the Base and Emfix runs represents the impact on $\mathrm{OH}$ of time varying, climate dependent isoprene emissions. The difference between the Base and Metfix runs represents the effect of inter-annual variations in meteorology.

The decreased isoprene emissions after 1990, as shown in Fig. 1, reduces a sink for $\mathrm{OH}$, increasing its concentration. The changing meteorology has the opposite effect, reducing concentrations of $\mathrm{OH}$ after 1991. This could relate to the drier conditions caused by the eruption of Mt. Pinatubo (Trenberth and Dai, 2007), causing lower atmospheric humidity and reducing production of $\mathrm{OH}$ via the reaction between $\mathrm{O}\left({ }^{1} \mathrm{D}\right)$ and $\mathrm{H}_{2} \mathrm{O}$, as well as the warmer phase of ENSO (Johnson et al., 2002), which leads to increases in the temperature dependent reaction between $\mathrm{CH}_{4}$ and $\mathrm{OH}$. The impact of changing isoprene emissions on the $\mathrm{OH}$ burden is of the same order of magnitude as the changing meteorology, indicating that this is an important effect which must be considered in any overall evaluation of the changing oxidising capacity. It is interesting that the peak effect of changing meteorology also coincides roughly with the minimum in the isoprene emissions. We also note that our use of non interactive photolysis excludes another source of variability in the $\mathrm{OH}$ column, as the aerosol cloud increases optical depth, decreasing $\mathrm{OH}$ production. This is offset by decreases in ozone after the eruption (Telford et al., 2009) decreasing optical depth and increasing $\mathrm{OH}$ production.

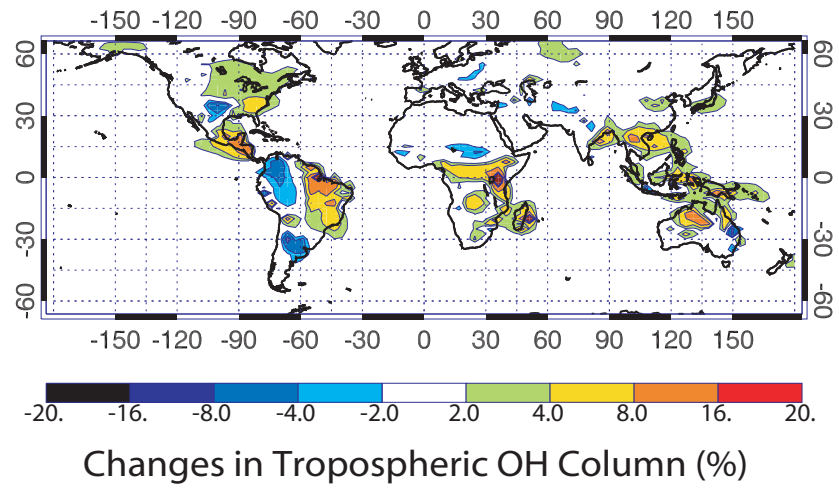

Fig. 5. Differences in tropospheric $\mathrm{OH}$ column between the Emfix and Base runs averaged over 1992. This corresponds to the difference between using 1992 and 1990 isoprene emissions.

The changes in $\mathrm{OH}$ also have an impact on the sink of methane. Because methane concentrations are fixed we cannot directly investigate this. Instead we have calculated the flux through the reaction $\mathrm{CH}_{4}+\mathrm{OH} \rightarrow \mathrm{H}_{2} \mathrm{O}+\mathrm{CH}_{3} \mathrm{OO}$ for each experiment. The effect of changes in emissions peaks in early 1993, when OH peaks, with an increase in this sink of methane of $5 \mathrm{Tg}\left(\mathrm{CH}_{4}\right) / \mathrm{yr}$. The effect of meteorology is to decrease the sink of methane by up to $14 \mathrm{Tg}\left(\mathrm{CH}_{4}\right) / \mathrm{yr}$. These changes are comparable to those estimated from biomass burning and wetland emissions (Bousquet et al., 2006). It is clear from our experiments that changes in emissions of non-methane VOCs are needed to fully explain changes in methane concentrations at this time. In contrast, the effect of changing isoprene emissions on ozone concentrations is found to be small, less than $0.1 \%$ on global air mass weighted concentrations. Changes to the production of aerosols from isoprene oxidation (Claeys et al., 2004) might be expected to be larger, though secondary organic aerosol formation was omitted from these simulations.

\subsection{Spatial distribution of changes to $\mathrm{OH}$}

We evaluate the spatial distribution of the $\mathrm{OH}$ changes by comparing tropospheric $\mathrm{OH}$ columns between the Base run and the Emfix run. The difference between the two is shown in Fig. 5 for 1992. The Base runs uses isoprene emissions for 1992 and the Emfix run uses isoprene emissions for 1990, so the change in emissions between the two runs can be seen in Fig. 2.

The effect on local $\mathrm{OH}$ concentrations is considerable, with changes of up to $20 \%$ modelled in Eastern Africa. The link between the changes in isoprene emissions, shown in Fig. 2, and $\mathrm{OH}$, shown in Fig. 5, is clear, with a spatial correlation coefficient of -0.6 . We have also considered the local changes of ozone, finding them to be locally non negligible, up to $2 \%$ in the Amazon basin, but as ozone is low in these regions this only has a small effect on global burdens. 


\subsection{Sensitivity of results to changes in the chemistry}

The absolute magnitude of changes in $\mathrm{OH}$ depends, of course, on our chemical scheme. We test our sensitivity to fixing methane by varying its concentration by $\pm 5 \%$ and find that the sensitivity of $\mathrm{OH}$ to emission changes is altered by less than $0.1 \%$.

We also note that there is uncertainty in the detailed treatment of isoprene oxidation (Lelieveld et al., 2008; Paulot et al., 2009; Archibald et al., 2009). To test our sensitivity to this uncertainty we modify the chemistry scheme in a simple way to introduce some parameterised recycling of $\mathrm{HO}_{\mathrm{x}}$ into the oxidation of isoprene. To do this we adopt a parameterised form of $\mathrm{HO}_{\mathrm{x}}$ production from the unimolecular decomposition of the isoprene hydroxy peroxy radicals (Peeters et al., 2009; da Silva et al., 2010). When we run the model with these changes over 1992 although we see large changes in the $\mathrm{OH}$ column (up to $100 \%$ over the Amazon basin) we find that the sensitivity to changes in the isoprene emissions is not much altered from the case where there is no $\mathrm{HO}_{\mathrm{x}}$ recycling. There is still much uncertainty on the oxidation of isoprene, and other, more sophisticated recycling schemes may produce different results again, so there remains a great deal of uncertainty on the exact value of our results. However the retention of the large inter-annual changes in the oxidising capacity suggests that changes in isoprene emissions are still capable of producing large changes in $\mathrm{OH}$.

\section{Conclusions}

Changes in climate, caused by amongst other factors the aftermath of the eruption of Mount Pinatubo and an El Niño warm event, are shown to have sizeable impacts on modelled isoprene emissions. The changing emissions have an impact on $\mathrm{OH}$, increasing tropospheric $\mathrm{OH}$ columns by up to $20 \%$ in regions such as eastern Africa. This change in $\mathrm{OH}$, the most important sink for methane, has an appreciable impact on the methane budget, being comparable to other drivers of its variability, such as changes in biomass burning. The reduced isoprene emissions after 1990 lead to an increase in the sink of methane of up to $5 \mathrm{Tg}\left(\mathrm{CH}_{4}\right)$ /year, contributing to the reduced growth rate observed at this time.

The cause of the changes in emissions are a result of changes to both the temperature and the hydrological cycle. Cooler temperatures throughout the tropics reduce isoprene emissions, though the ENSO warm phase causes regional warming. Even in regions which are warmer there are still areas of reduced emissions caused by decreases in biomass. These decreases are driven by drier conditions, linked to both the eruption and the ENSO warm phase.

The effect of climate dependent isoprene emissions is predicted to have a sizeable impact on atmospheric chemistry, through changes to the oxidising capacity of the troposphere. Although a large uncertainty remains as to the exact impact, due to factors such as our incomplete understanding of isoprene oxidation, the magnitude of the effect is large enough that it cannot be neglected. This demonstrates the importance of modelling the whole Earth system to understanding changes in atmospheric chemistry.

Although some coupling processes, such as the impact of stratospheric ozone reductions on tropospheric UV radiation were not included, our study has highlighted some important interactions. As Earth system models increase in sophistication these sensitivity studies will be replaced by more complete simulations of past and future changes,

Acknowledgements. This work was supported by NCAS and QUEST. We also acknowledge support through the EU FP6 Integrated Programme, SCOUT-O3(505390-GOCE-CT-2004). We acknowledge Paul Berrisford and the ECMWF for the ERA-40 data. The development of the UKCA model (www.ukca.ac.uk) was supported by the Joint DECC and Defra Integrated Climate Programme - DECC/Defra (GA01101) - and the Natural Environment Research Council (NERC) through the NCAS initiative.

\section{References}

Archibald, A., Jenkin, M., and Shallcross, D.: An isoprene mechanism intercomparison, Atmos. Env., doi:10.1016/j.atmosenv. 2009.09.016, in press, 2009.

Barkley, M., Palmer, P., Kuhn, U., Kesselmeier, J., Chance, K., Kurosu, T., Martin, R., Helmig, D., and Guenther, A.: Net ecosystem flux of isoprene over tropical South America inferred from Global Ozone Monitoring Experiment (GOME) observation of HCHO columns, J. Geophys. Res., 113, D20304, doi: 10.1029/2008JD009863, 2008.

Beerling, D., Woodward, F., Lomas, M., and Jenkins, A.: Testing the responses of a dynamic global vegetation model to environmental change: a comparison of observations and predictions, Global Ecol. Biogeogr. Lett., 6, 439-50, 1997.

Beerling, D. J. and Woodward, F. I.: Vegetation and the terrestrial carbon cycle. Modelling the first 400 million years, Cambridge University Press, 2001.

Bekki, S., Law, K., and Pyle, J.: Effect of ozone depletion on atmospheric $\mathrm{CH}_{4}$ and $\mathrm{CO}$ concentrations, Nature, 371, 595-597, 1994.

Bousquet, P., Hauglustaine, D. A., Peylin, P., Carouge, C., and Ciais, P.: Two decades of $\mathrm{OH}$ variability as inferred by an inversion of atmospheric transport and chemistry of methyl chloroform, Atmos. Chem. Phys., 5, 2635-2656, doi:10.5194/acp-52635-2005, 2005.

Bousquet, P., Ciais, P., Miller, J. B., Dlugokencky, E. J., Hauglustaine, D. A., Prigent, C., der Werf, G. R. V., Peylin, P., Brunke, E.-G., Carouge, C., Langenfelds, R. L., Lathière, J., Papa, F., Ramonet, M., Schmidt, M., Steele, L. P., Tyler, S. C., and White, J.: Contribution of anthropogenic and natural sources to atmospheric methane variability, Nature, 443, 439-443, 2006.

Claeys, M., Graham, B., Vas, G., Wang, W., Vermeylen, R., Pashynka, V., Cafmeyer, J., Guyon, P., Andreae, M., Artaxo, P., and Maenhaut, W.: Formation of Secondary Organic Aerosols Through Photooxidation of Isoprene, Science, 303, doi:10.1126/ science.1092805, 2004. 
da Silva, G., Graham, C. and Wang, Z.-F.: Unimolecular $\beta$ Hydroxyperoxy Radical Decomposition with $\mathrm{OH}$ recycling in the Photochemical Oxidation of Isoprene, Environ. Sci. Technol., 44, 250-256, 2010

Dalsøren, S. and Isaksen, I.: CTM study of changes in tropospheric hydroxyl 1-7, 2006.

Denman, K., Brasseuer, G., Chidthaisong, A., Ciais, P., Cox, P., Dickinson, R., Hauglustaine, D., Heinze, C., Holland, E., Jacob, D., Lohmann, U., Ramachandran, S., de Silva, P., Wofsy, S., and X. Zhang, L.: Climate Change 2007: The Physical Science Basis, chap. Couplings Between Changes in the Climate System and Biogeochemistry, Cambridge University Press, 499587, 2007.

Dlugokencky, E., Houweling, S., Bruhwiler, L., Masarie, K., Lang, P., Miller, J., and Tans, P.: Atmospheric methane levels off: Temporary pause or a new steady-state?, Geophys. Res. Lett., 30, 1992, doi:10.1029/2003GL018126, 2003.

Eyers, C., Addleton, D., Atkinson, K., Broomhead, M., Christou, R., Elliff, T., Falk, R., Gee, I., Lee, D., Marizy, C., Michot, S., Middel, J., Newton, P., Norman, P., Plohr, M., Raper, D., and Stanciou, N.: AERO2K global aviation emissions inventories for 2002 and 2025, Tech. Rep. QinetiQ/04/01113, Qinetiq, 2004.

Gedney, N., Cox, P., and Huntingford, C.: Climate feedback from wetland methane emissions, Geophys. Res. Lett., 31, L20503, doi:10.1029/2004GL020919, 2004.

Giannakopoulos, C., Chipperfield, M., Law, K., and Pyle, J.: Validation and intercomparison of wet and dry deposition schemes using $\mathrm{Pb}-210$ in a global three-dimensional off-line chemical transport model, J. Geophys. Res., 104, 23761-23784, 1999.

Guenther, A., Karl, T., Harley, P., Wiedinmyer, C., Palmer, P., and Geron, C.: Estimates of global terrestrial isoprene emissions using MEGAN (Model of Emissions of Gases and Aerosols from Nature), Atmos. Chem. Phys., 6, 3181-3210, 2006,

http://www.atmos-chem-phys.net/6/3181/2006/.

Johnson, C., Stevenson, D., Collins, W., and Derwent, R.: Interannual variability in methane growth rate simulated with a coupled Ocean-Atmosphere-Chemistry model, Geophys. Res. Lett., 29, 1903, doi:10.1029/2002GL015269, 2002.

Krol, M. and Lelieveld, J.: Can the variability in tropospheric $\mathrm{OH}$ be deduced from measurements of 1,1,1trichloroethane (methyl chloroform)?, J. Geophys. Res., 108, 4125, doi:10.1029/2002JD002423, 2003.

Lathière, J., Hauglustaine, D. A., Friend, A. D., De NobletDucoudré, N., Viovy, N., and Folberth, G. A.: Impact of climate variability and land use changes on global biogenic volatile organic compound emissions, Atmos. Chem. Phys., 6, 2129-2146, doi:10.5194/acp-6-2129-2006, 2006.

Lathière, J., Hewitt, N., and Beerling, D.: Sensitivity of isoprene emissions from the terrestrial biosphere to 20th century changes in atmospheric $\mathrm{CO} 2$ concentration, climate and land use, Global Biogeochemical Cycles, 24, GB1004, doi:10.1029/2009GB003548, 2010.

Law, K. and Pyle, J.: Modeling trace gas budgets in the troposphere.1. ozone and odd nitrogen, J. Geophys. Res., 98, 1837718400, 1993a.

Law, K. and Pyle, J.: Modeling trace gas budgets in the troposphere 2. $\mathrm{CH}_{4}$ and CO, J. Geophys. Res., 98, 18,401-18,412, 1993 b.

Law, K., Plantevin, P., Shallcross, D., Rogers, H., Pyle, J., Grouhel, C., Thouret, V., and Marenco, A.: Evaluation of modeled $\mathrm{O}_{3}$ using Measurement of Ozone by Airbus In-Service Aircraft (MOZAIC) data, J. Geophys. Res., 103, 25721-25737, 1998.

Lelieveld, J., Crutzen, P., and Dentener, F.: Changing concentration, lifetime and climate forcing of atmospheric methane, Tellus B Chem. Phys. Meteorol., 50, 128-150, 1998.

Lelieveld, J., Butler, T., Crowley, J., Dillon, T., Fischer, H. L. G., Harder, H., Lawrence, M., Martinez, M., Taraborrelli, D., and Williams, J.: Atmospheric oxidation capacity sustained by a tropical forest., Nature, 452, 737-740, 2008.

McCormick, M., Thomason, L., and Trepte, C.: Atmospheric Effects of the Mount Pinatubo Eruption, Nature, 373, 399-405, 1995.

Milton, S. and Dean, W.: Disturbance, drought and dynamics of desert dune grassland, South Africa, Plant Ecol., 150, 37-51, 2000.

Morgenstern, O., Braesicke, P., O’Connor, F. M., Bushell, A. C., Johnson, C. E., Osprey, S. M., and Pyle, J. A.: Evaluation of the new UKCA climate-composition model - Part 1: The stratosphere, Geosci. Model Dev., 2, 43-57, doi:10.5194/gmd-2-432009, 2009.

Müller, J.-F., Stavrakou, T., Wallens, S., Smedt, I. D., Roozendael, M. V., Potosnak, M. J., Rinne, J., Munger, B., Goldstein, A., and Guenther, A. B.: Global isoprene emissions estimated using MEGAN, ECMWF analyses and a detailed canopy environment model, Atmos. Chem. Phys., 8, 1329-1341, doi:10.5194/acp-81329-2008, 2008.

O'Connor, F., Johnson, C., Morgenstern, O., and Collins, W. J.: Interactions between tropospheric chemistry and climate model temperature and humidity biases, Geophys. Res. Lett, 36, L16801, doi:doi:10.1029/2009GL039152, 2009.

O’Connor, F., Johnson, C., Morgenstern, O., Sanderson, M., Young, P., Collins, W., and J. Pyle, J. A.: Evaluation of the new UKCA climate-composition model - Part 2: The Troposphere, Geosci. Model Dev. Discuss., in preparation, 2010.

Paulot, F., Crounse, J., Kjaergaard, H., Kürten, A., St. Clair, J., Seinfeld, J., and Wennberg, P.: Unexpected Epoxide Formation in the Gas-Phase Photooxidation of Isoprene, Science, 325, 730 733, 2009.

Peeters, J. , Nguyen, T. and Vereecken, L.:HO $\mathrm{HO}_{x}$ radical regeneration in the oxidation of isoprene, Phys. Chem. Chem. Phys., 11, 5935-5939, doi:10.1039/b908511d, 2009.

Pike, R. C., Lee, J. D., Young, P. J., Moller, S., Carver, G. D., Yang, X., Misztal, P., Langford, B., Stewart, D., Reeves, C. E., Hewitt, C. N., and Pyle, J. A.: Can a global model chemical mechanism reproduce $\mathrm{NO}, \mathrm{NO}_{2}$, and $\mathrm{O}_{3}$ measurements above a tropical rainforest?, Atmos. Chem. Phys. Discuss., 9, 27611-27648, doi:10.5194/acpd-9-27611-2009, 2009.

Pöschl, U., von Kuhlmann, R., Poisson, N., and Crutzen, P.: Development and intercomparison of condensed isoprene oxidation mechanisms for global atmospheric modelling, J. Atmos. Chem., 37, 29-52, 2000.

Price, C. and Rind, D.: Modelling global lightning distributions in a general circulation model, Mon. Weath. Rev., 122, 1930-1939, 1994.

Qian, H., Joseph, R., and Zeng, N.: Response of the terrestrial carbon cycle to the El Niño-Southern Oscillation, Tellus B - Chem. Phys. Meteorol., 60, 537-550, 2008.

Rayner, A., Rayner, N., Parker, D., Horton, E., Folland, C., Alexander, L., Rowell, D., Kent, E., and Kaplan, A.: Global analyses 
of sea surface temperature, sea ice, and night marine air temperature since the late nineteenth century, J. Geophys. Res., 108D, 4407, doi:10.1029/2002JD002670, 2003.

Sanderson, M., Jones, C., Collins, W., Johnson, C., and Derwent, R.: Effect of climate change on isoprene emissions and surface ozone levels, Geophys. Res. Lett, 30, 1936, doi:doi:10.1029/ 2003GL017642., 2003.

Sharkey, T., Wiberley, A., and Donohue, A.: Isoprene Emission from Plants: Why and How, Ann. Botany, 10, 1-14, doi:10.1093/ aob/mcm240, 2007.

Stevenson, D., Dentener, F., Schultz, M., Ellingsen, K., van Noije, T., Wild, O., Zeng, G., Amann, M., Atherton, C., Bell, N., Bergmann, D., Bey, I., Butler, T., Cofala, J., Collins, W., Derwent, R., Doherty, R., Drevet, J., Eskes, H., Fiore, A., Gauss, M., Hauglustaine, D., Horowitz, L., Isaksen, I., Krol, M., Lamarque, J.-F., Lawrence, M., Montanaro, V., ller, J.-F. M., Pitari, G., Prather, M., Pyle, J., Rast, S., Rodriguez, J., Sanderson, M., Savage, N., Shindell, D., Strahan, S., Sudo, K., and Szopa, S.: Multimodel ensemble simulations of present-day and nearfuture tropospheric ozone, J. Geophys. Res., 111, D08301, doi: 10.1029/2005JD006338, 2006.

Telford, P. J., Braesicke, P., Morgenstern, O., and Pyle, J. A.: Technical Note: Description and assessment of a nudged version of the new dynamics Unified Model, Atmos. Chem. Phys., 8, 17011712, doi:10.5194/acp-8-1701-2008, 2008.

Telford, P., Braesicke, P., Morgenstern, O., and Pyle, J.: Reassessment of Causes of Ozone Column Variability following the Eruption of Mount Pinatubo using a nudged CCM, Atmos. Chem. Phys., 9, 4251-4260, doi:10.5194/acp-9-4251-2009, 2009.

Tian, H., Melillo, J., Kicklighter, D., McGuire, A., Helfrich III, J., Moore III, B., and Vörösmarty, C.: Effect of interannual climate variability on carbon storage in Amazonian ecosystems, Nature, 396, 664-667, 1998.

Trenberth, K. and Dai, A.: Effects of Mount Pinatubo volcanic eruption on the hydrological cycle as an analog of geoengineering, Geophys. Res. Lett., 34, 15702, doi:10.1029/ 2007GL030524, 2007.
Uppala, S., Kallberg, P., Simmons, A., Andrae, U., Da Costa Bechtold, V., Fiorino, M., Gibson, J., Haseler, J., Hernandez, A., Kelly, G., Li, X., Onogi, K., Saarinen, S., Sokka, N., Allan, R., Andersson, E., Arpe, K., Balmaseda, M., Beljaars, A., van de Berg, L., Bidlot, J., Bormann, N., Caires, S., Chevallier, F., Dethof, A., Dragosavac, M., Fisher, M., Fuentes, M., Hagemann, S., Holm, E., Hoskins, B., Isaksen, L., Janssen, P., Jenne, R., McNally, A., Mahfouf, J.-F., Morcrette, J.-J., .Rayner, N., Saunders, R., Simon, P., Sterl, A., Trenberth, K., Untch, A., Vasiljevic, D., Viterbo, P., and Woollen, J.: The ERA-40 re-analysis, Q. J. Roy. Meteor. Soc., 131, 2961-3012, 2005.

Wang, J., Logan, J., McElroy, M., Duncan, B., Megretskaia, I., and Yantosca, R.: A 3-D model analysis of the slowdown and interannual variability in the methane growth rate from 1988-1997, Global Biogeochem. Cy., 18, GB3011, doi:10.1029/2003GB002180, 2004.

Warwick, N., Bekki, S., Law, K., Nisbet, E., and Pyle, J.: The impact of meteorology on the interannual growth rate of atmospheric methane, Geophys. Res. Lett., 29, 1947, doi:10.1029/2002GL015282, 2002.

Wolter, K. and Timlin, M.: Monitoring ENSO in COADS with a seasonally adjusted principal component index, in: Proc. of the 17th Climate Diagnostics Workshop, Norman, OK, NOAA/N MC/CAC, NSSL, Oklahoma Clim. Survey, CIMMS and the School of Meteor., Univ. of Oklahoma, 52-57, 1993.

Young, P. J., Arneth, A., Schurgers, G., Zeng, G., and Pyle, J. A.: The $\mathrm{CO}_{2}$ inhibition of terrestrial isoprene emission significantly affects future ozone projections, Atmos. Chem. Phys., 9, 27932803, doi:10.5194/acp-9-2793-2009, 2009.

Zeng, G. and Pyle, J. A.: Changes in tropospheric ozone between 2000 and 2100 modeled in a chemistry-climate model, Geophys. Res. Lett., 30, 1392, doi:10.1029/2002GL016708, 2003. 